\title{
Nové poznatky o šibenici v Bystřici nad Pernštejnem
}

\author{
Robin Pěnička \\ Ústav antropologie, Přírodovědecká fakulta Masarykovy univerzity; Kotlářská 267/2, 61137 Brno \\ Do redakce doručeno 26. listopadu 2020; k publikaci přijato 6. dubna 2021
}

\section{NEW FINDINGS AT THE GALLOWS SITE IN BYSTŘICE NAD PERNŠTEJNEM, MORAVIA, CZECH REPUBLIC}

\begin{abstract}
The municipal gallows in Bystřice nad Pernštejnem was located on a well visible hill south of the urban development. From the original gallows of a square to slightly trapezoidal shape with an outer length of 4 to $4.5 \mathrm{~m}$, a stone fence has been preserved up to a height of $65 \mathrm{~cm}$. The inner part of the gallows was uncovered, where there were layers of stones, pearl waste and building layers of detritus. At places interspersed with a humus-like interlayer containing numerous human bones, which some were scattered and some placed in anatomical position. At the bottom of the gallows was discovered an intact grave of a young boy around the age of 13 years. During excavation of the gallows site were found fragments of ceramics, which can be dated from the turn of the $15^{\text {th }}$ and $16^{\text {th }}$ centuries to 18th century; hooks and loops clasps and buttons were a common part of contemporary garments; nails, a knife and a sickle were associated with on-site operations. The Czech, Polish and Carinthian coins date back to the $15^{\text {th }}$ to $17^{\text {th }}$ centuries. After the end of the research, the inner space of the gallows and its surroundings were modified in connection with the construction of a forest trail.
\end{abstract}

KEY WORDS Bystřice nad Pernštejnem; gallows; judiciary; modern age, archaeology; preliminary report

ABSTRAKT Městské popraviště v Bystřici nad Pernštejnem se nacházelo na dobře viditelném kopci jižně od městské zástavby. Z původní šibenice čtvercového až mírně lichoběžníkovitého tvaru o vnější délce 4 až $4,5 \mathrm{~m}$ se dochovalo do výšky $65 \mathrm{~cm}$ kamenné ohrazení. Zkoumaná byla vnitřní část šibenice, kde se nacházely vrstvy kamenů, perletářského odpadu a suti proložené humusovitou mezivrstvou s četnými rozptýlenými i anatomický uspořádanými lidskými kostmi. Na dně šibenice byl odkryt neporušený hrob chlapce ve věku kolem 13 let. Při odkryvu vnitřní výplně šibenice se našly zlomky keramiky datovatelné od přelomu 15. a 16. století do 18. století; nalezené záponky typu háček a očko a knoflíky byly běžnou součástí oděvu; hřebíky, železný nůž a srp pravděpodobně souvisely s provozem na místě. Nalezené stř́ibrné mince české, polské a korutanské ražby jsou datovatelné do 15. až 17. století. Sondáží byla zkoumaná terénní hrana, která vymezovala areál popraviště. Po ukončení výzkumu byl vnitřní prostor šibenice a její okolí upraveno v souvislosti s budováním lesní stezky.

KLÍČOVÁ SLOVA Bystřice nad Pernštejnem; šibenice; justice; novověk; archeologie; předběžná zpráva

Ve středověku a raném novověku patř̀ila veřejná popraviště k výrazným krajinným prvkům, které od konce 18. století postupně mizely a jejich stopa $\mathrm{v}$ dnešní krajině je téměř neviditelná. Dosavadní výzkum moravských šibenic přinesl poznatky o jejich poloze, stavební podobě, o provozu, ale také o delikventech, kteří byli na šibenici popraveni a jejichž tělesné pozůstatky nacházíme v blízkosti popraviště. Na podkladech Prvního vojenského mapování byla provedena rekognoskace reliktů popravišt přímo $\mathrm{v}$ terénu a bylo provedeno několik archeologických výzkumu šibenic (Tišnov, Křenovice/Slavkov u Brna, Ivančice, Šatov). Výsledky studia morav- ských šibenic byly průběžně publikovány (Balážová 2018; Čuta - Mořkovský 2017; Havlát et al. 2015; Jurkovičová 2017; Káčerková - Boriová 2019; Křápková 2017; Pěnička 2014; 2017a; 2017b; 2019; Unger 2014; 2017a; 2017b; 2019a; 2019b; Unger et al. 2016; Virdzeková 2016a) a jejich souhrn, doplněný o nejnovější poznatky, byl uveden $\mathrm{v}$ kolektivní publikaci Jihomoravské šibenice $v$ časném novověku (16. až 18. století) (Unger et al. 2020). V několika př́padech vyústil odborný výzkum v duchovní, pietní a turistickou úpravu místa někdejšího popraviště souvisejícího s právním postavením města v minulosti. Další lokalitou, které byla věnována pozornost, 


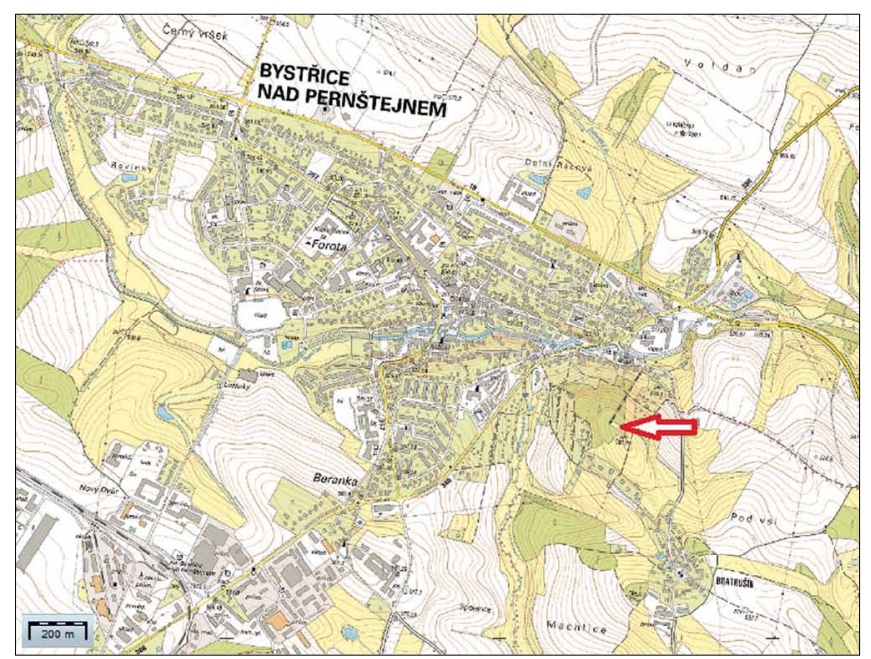

Obr. 1. Základní mapa ČR (1:10 000) s lokalizací šibenice (označeno šipkou).

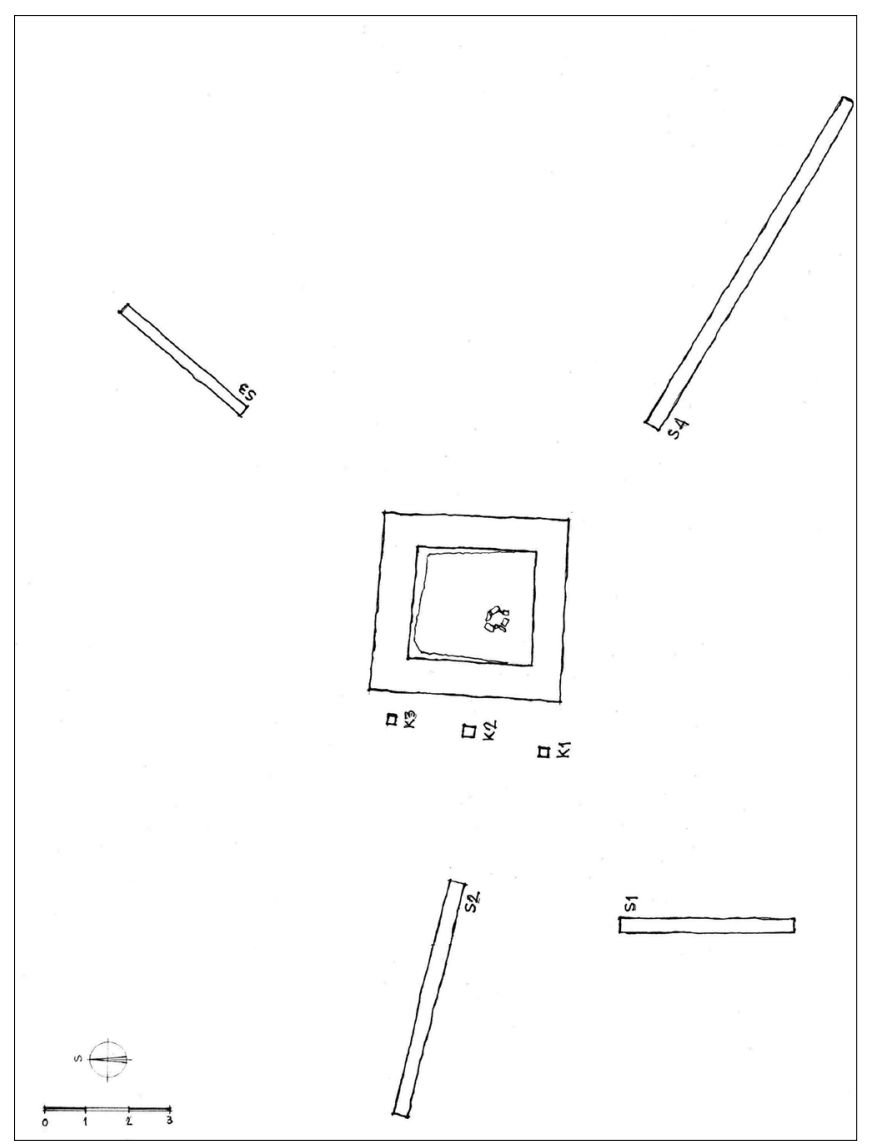

Obr. 2. Celkový plán prozkoumané plochy. S1 - S4: sondy detekující ohrazení areálu, K1 - K3: kamenné kříže z r. 1854 na západní straně šibenice. Kresba: J. Velek.

je šibenice v Bystřici nad Pernštejnem. Pozůstatky šibenice se nachází jihovýchodně od města na výrazné vyvýšenině, která dominuje na pravém břehu říčky Bystřice, do jejíhož údolí spadá ukloněnými svahy (Obr. 1). Pozůstatky šibenice leží ve vrcholové části hřbetu vyvýšeniny ve směru SZ-JV v nadmořské výšce $593 \mathrm{~m}$. Na Prvním vojenském mapování z let

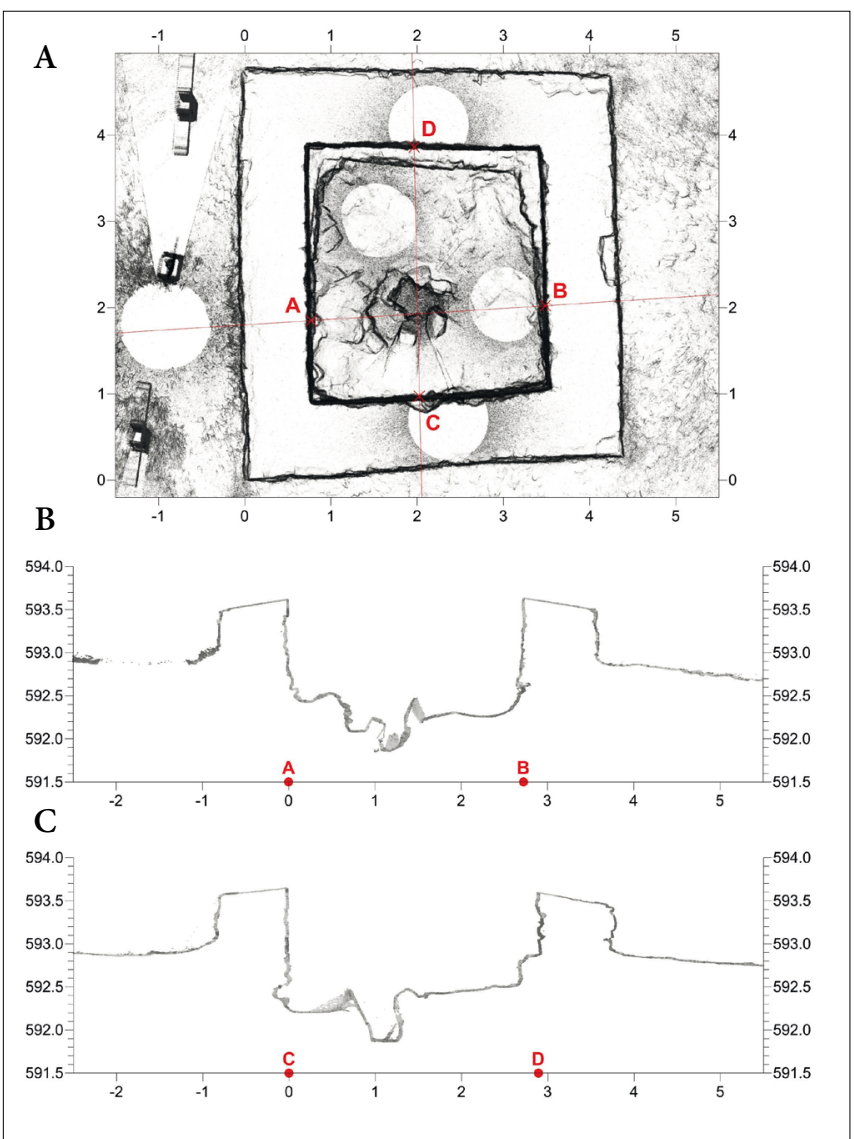

Obr. 3. Polohopisné a výškopisné zaměření šibenice, včetně řezů šibenicí. A: půdorys šibenice, $\mathrm{B}$ : západo-východní řez $\mathrm{A}-\mathrm{B}$, C: jiho-severní řez $\mathrm{C}-\mathrm{D}$. Podle laserového skenování zpracoval Fr. Kuda.

1764-1768 (Morava, mapový list č. 35), je šibenice zakreslena jako čtyřkůlová stavba bez kamenné základny. Na Druhém vojenském mapování z let 1836-1852 (Morava, mapová list W_7_I) již není šibenice zakreslena a místo, kde stávala je označené jako „Galgen B.“ Při Třetím vojenském mapování z let 1876-1878 (1:25 000, mapový list 4156_4) bylo místo bývalého popraviště označeno jako Hora a na místě šibenice byly zaznačeny tři kamenné kř́iže. Na indikační skice a císařském otisku stabilního katastru z 30 . let 19. století se místo v okolí zaniklé šibenice označuje jako Spojence.

Nejstarší doklad hrdelního soudu městečka Bystřice nad Pernštejnem pochází z počátku 15. století, avšak orientace tohoto soudu na právo města Hradce Králové naznačuje, že jeho kořeny je nutné hledat již na přelomu 12. a 13. století (Štarha 2007, 133-134). Působnost bystřického hrdelního soudu je doložena zápisem z roku 1416, kdy byl v Bystřici souzen a oběšen lapka Šrám, člen loupežnické skupiny ve službách Viléma z Pernštejna. Činy této lapkovské družiny byly patrně rozsáhlé a záznam o výslechu a popravě Šráma se dostal až do jihlavských městských knih (Štarha 1998, 8; Štarha 2007, 134; Smrčková 2020, 40). Cenným pramenem o činnosti hrdelního soudu jsou tzv. výběrky na kata z roku 1483, zapsané $\mathrm{v}$ nejstarší bystřické městské knize. Výběrka nebyla platba na bystřického mistra popravního, nebot' téměř po celou 


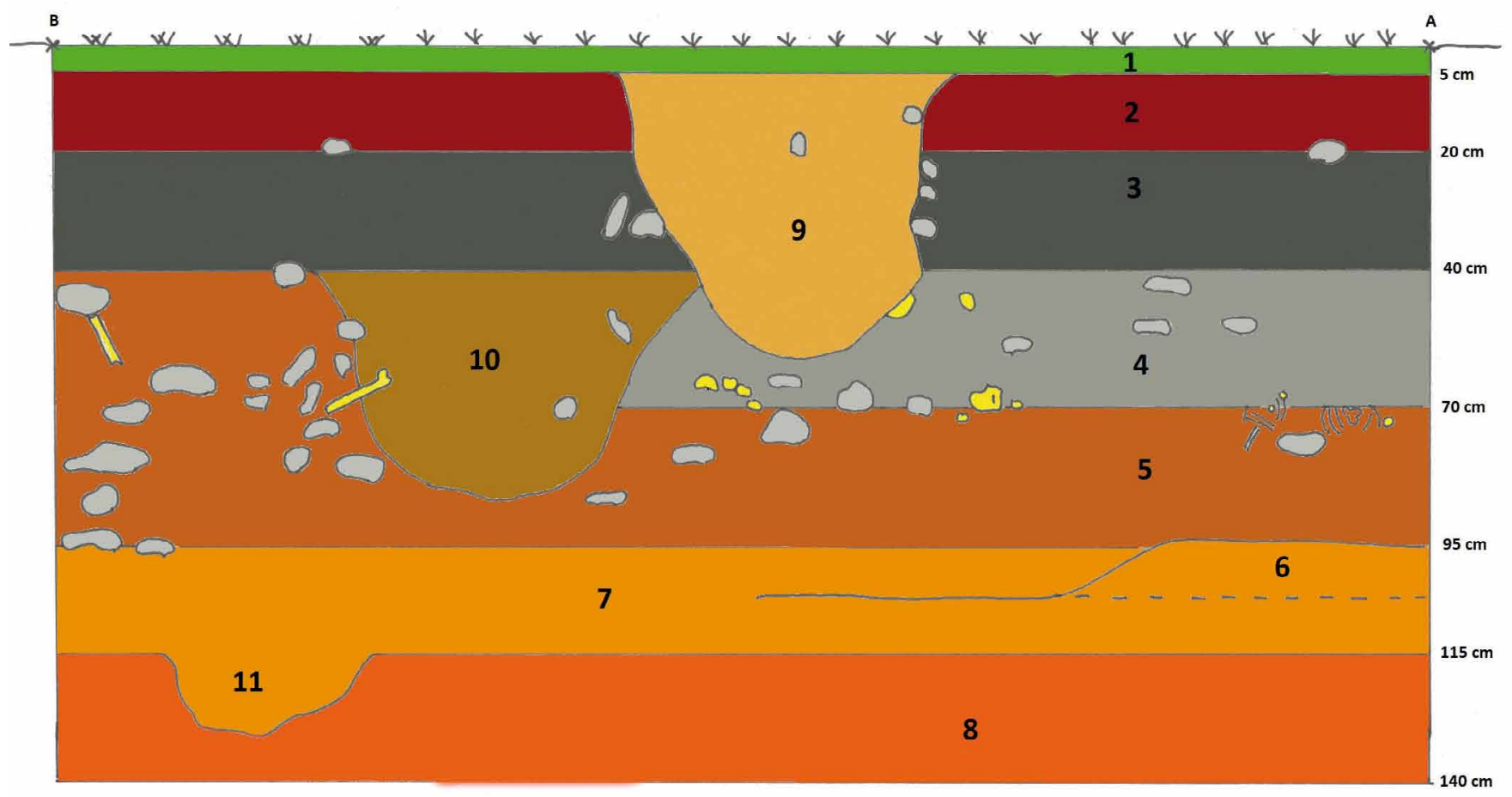

Obr. 4. Profil výplně šibenice mezi západním (A) a východním (B) zdivem šibenice. 1 - podpovrchová vrstva s drny, 2 - vrstva hnědo-černé hlíny, 3 - vrstva hlíny s lasturami a perletářským odpadem, 4 - vrstva tvořená směsicí hlíny, malty, kameny a ojedinělých kostí, 5 - vrstva s kosterními pozůstatky, maltou a kameny, 6 - krusta vylité malty (podlaha?), 7 - vrstva hnědočervené zeminy s ojedinělými nálezy kostí, 8 - vrstva červené rozvětrané skály, 9 - jáma vyplněná šedo-hnědým zásypem, 10 - jáma vyplněná světlým zásypem tvořeným směsí malty, kamení a kostí, 11 - jáma do skalnatého podloží vyplněná maltou a kostmi. Kameny šedou barvou, kosti žlutou barvou. Kresba: R. Pěnička.

dobu existence hrdelního soudu si městečko půjčovalo kata z města Poličky. Dokazuje to účet za popravu v roce 1483, kdy byli oběšeni Hynek Šimon a Sedlák. Záhy po této popravě je v městské knize další zápis o popravě, tentokrát Barchoně $\mathrm{z}$ Olešnice, na kterou musela bystřická obec poskytnout mimořádnou dotaci (Štarha 2007, 135). Vlastního kata měla Bystřice až na sklonku 17. století, kdy se k roku 1680 uvádí jako městský kat Jan Hanuš. V roce 1687 bylo pod Šibeniční horou postaveno obydlí pro kata a za bystřického mistra popravního byl přijat Tomáš Trucálek (Tenora 1909, 95; Štarha 1998, 9; Štarha 2007, 135). Ve složitých hrdelních sporech se bystřický městský soud obracel prostřednictvím města Poličky na právní naučení Hradce Králové, která jsou doložená mezi léty 1441 až 1572 (civilněprávní spory, Hradec Králové), resp. mezi léty 1441 až 1588 (trestní a kriminální spory, Polička) (Štarha 1970, 307; Štarha 2007, 135-136). Po nabytí městských práv na konci 16. století se Bystřice od královehradeckého práva osamostatnila a pozdější právní naučení získávala z Brna (Štarha 1970, 310-311). Od počátku 16. století se územní rozsah působení bystřického hrdelního soudu podstatně zmenšil a jednotlivé vesnice a městečka se odtrhovala k sousedním panstvím, až se územní rozsah působení hrdelního soudu omezil jen na bystřické panství. Se zmenšováním obvodu hrdelního soudu klesal i jeho význam, jenž na přelomu 17. a 18. století poklesl natolik, že v rámci restrikčních narrízení císaře Karla VI. byl v roce 1729 bystřický hrdelní soud zrušen (Tenora 1907, 53; Štarha 1998, 8; Štarha 2007, 137).
Hrdelní soud byl sice na naléhání bystřické městské rady obnoven, ale od konce třicátých let 18 . století jeho význam opět poklesl a lze předpokládat jeho další omezování. K celkovému zániku bystřického hrdelního soudu pravděpodobně došlo $\mathrm{v}$ rámci tereziánských soudních reforem v polovině 18 . století. Zjištovací archeologický výzkum bystřické šibenice proběhl na přelomu jara a léta 2020 na vrcholu Šibeniční hory, kde jsou dochovány obvodové zdi původního popraviště. Lokalita je $\mathrm{z}$ hlediska reliéfu situována $\mathrm{v}$ geomorfologickém celku Hornosvratecká vrchovina. Hranici mezi geomorfologickými podcelky tvoří říčka Bystřice, na pravém břehu se nachází podcelek Nedvědická vrchovina (s Šibeniční horou) a na levém břehu podcelek Ždárské vrchy s méně členitým reliéfem a s městskou zástavbou (Kirchner 2020). V současné době jsou severní a severozápadní svahy zalesněny, místy s travními porosty. $\mathrm{V}$ úzkém odlesněném pruhu je vedena trasa lyžařského vleku. Původně byl prostor Šibeniční hory nezalesněný a byl pokryt převážně pastvinami. K zalesnění příkrých severních a severovýchodních svahů došlo až v roce 1853. Šibenice byla vybudována na skalním podloží tvořeného metamorfovanými horninami svrateckého krystalinika (paleozoikum - proterozoikum), kde převažují dvojslídné migmatity a ortoruly, dvojslídné svory s granáty, pararuly a svorové ruly. V prostoru samotné šibenice se nacházejí převážně dvojslídné migmatity až ortoruly, jižně pak zasahují svory (Kirchner 2020). Vrchol Šibeniční hory byl výrazně ovlivněn lidskými aktivitami nejen při výstavbě šibenice, ale především $\mathrm{v}$ souvislosti $\mathrm{s}$ bu- 


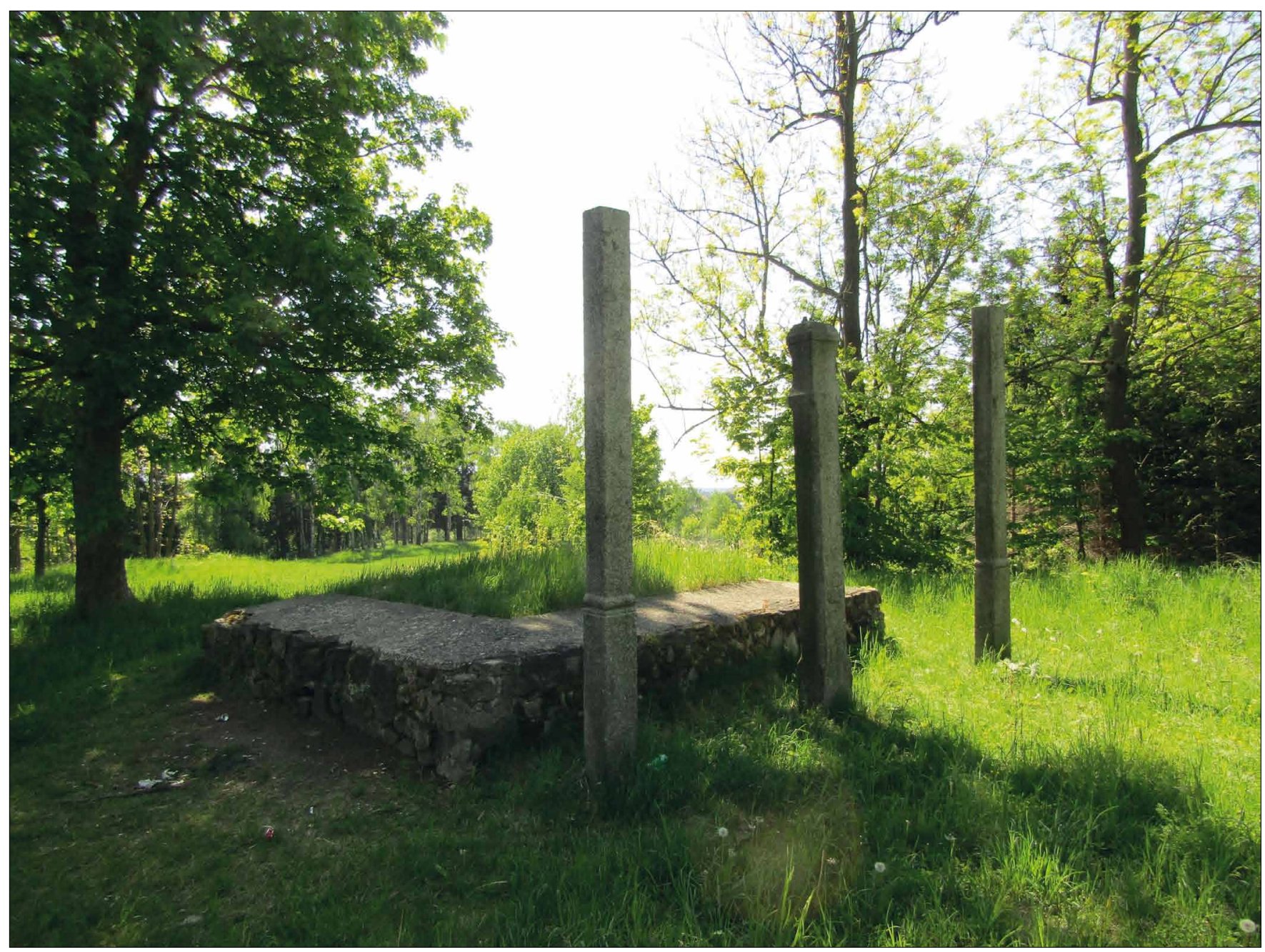

Obr. 5. Severozápadní pohled na šibenici před exkavací a rekonstrukcí kamenných křížů z roku 1853. Foto: R. Pěnička.

dováním lyžařského vleku. Tehdy byl okolní terén vyrovnán a shrnutá zemina byla navršena na haldu v severozápadní části vrcholové plošiny. Zemina byla navršena i v okolí kamenného ohrazení šibenice. Tyto aktivity setřely původní rysy reliéfu, které dotvářely ohrazení popraviště. To je doposud patrné $\mathrm{v}$ podobě terénní hrany $\mathrm{v}$ linii vzrostlých stromů severně a severovýchodně od šibenice. S ohledem na značně antropogenně pozměněnou vrcholovou část Šibeniční hory př̀i výstavbě lyžařského vleku, je dosti složité detekovat původní reliéf v okolí šibenice, včetně možnosti detekce kosterních pozůstatků popravených osob a dalších zařízení popraviště.

Vlastní výzkum šibenice se soustředil na její vnitřní prostor a nejbližší okolí dochovaného zdiva. Několika sondami byla prozkoumána výraznější terénní hrana $\mathrm{v}$ místě původního ohrazení areálu popraviště (Obr. 2, Obr. 3). Kamenné ohrazení šibenice čtvercového až mírně lichoběžníkového půdorysu se dochovalo do výšky $65 \mathrm{~cm}$ a bylo tvořeno lámaným kamenem položeným na maltu (Obr. 6). Korunu zdiva tvoří vrstva betonu z roku 1988. Západní hrana zdiva (délka 480 cm) a východní hrana zdiva (délka $440 \mathrm{~cm}$ ) byla orientována ve směru S-J, kratší jižní hrana zdiva (délka $440 \mathrm{~cm}$ ) a severní hrana zdiva (délka $430 \mathrm{~cm}$ ) byla orientována ve směru V-Z. Šírka zdiva byla na všech hranách $90 \mathrm{~cm}$. U delší (západní) hrany šibenice se nacházejí tři kamenné kř́řže z roku 1853 (Obr. 5). Podle různých typologií se jednalo o šibenici studničního typu na čtvercovém půdorysu, který se na Moravě vyskytuje nejčastěji (Wojtucki 2005, 27-30; Evers 2008, 448-455; Virdzeková 2016b, 15). Po odstranění výplně vnitřního prostoru šibenice bylo v hloubce 140 až $150 \mathrm{~cm}$ od horní hrany zdiva dosaženo skalní podloží, tvořené zvětralou ortorulou. Od povrchu činí hloubka dna výplně šibenice 85 až $95 \mathrm{~cm}$. Vnitřní prostor s kosterními pozůstatky byl vyplněn převážně hlínou s množstvím kamenů a balvanů místního původu (ortoruly, aplitické ruly, svory svrateckého krystalinika). Z těchto hornin byla vystavěna i obvodová zed' šibenice starší i mladší stavební fáze. Ve střední části šibenice v kontaktu se skalním podložím bylo odkryto dílčí zahloubení, které bylo kruhovitě vymezeno balvany ortorul. Toto vymezení indikuje původní upevnění dřevěného kůlu nejstarší (dřevěné) fáze šibenice. Ve výplni šibenice bylo identifikováno několik vrstev (Obr. 4). Vrstva 1 (hloubka 0-5 cm). Recentní vrstva drnů a podpovrchová vrstva byla zarovnána s korunou dochovaného zdiva. 


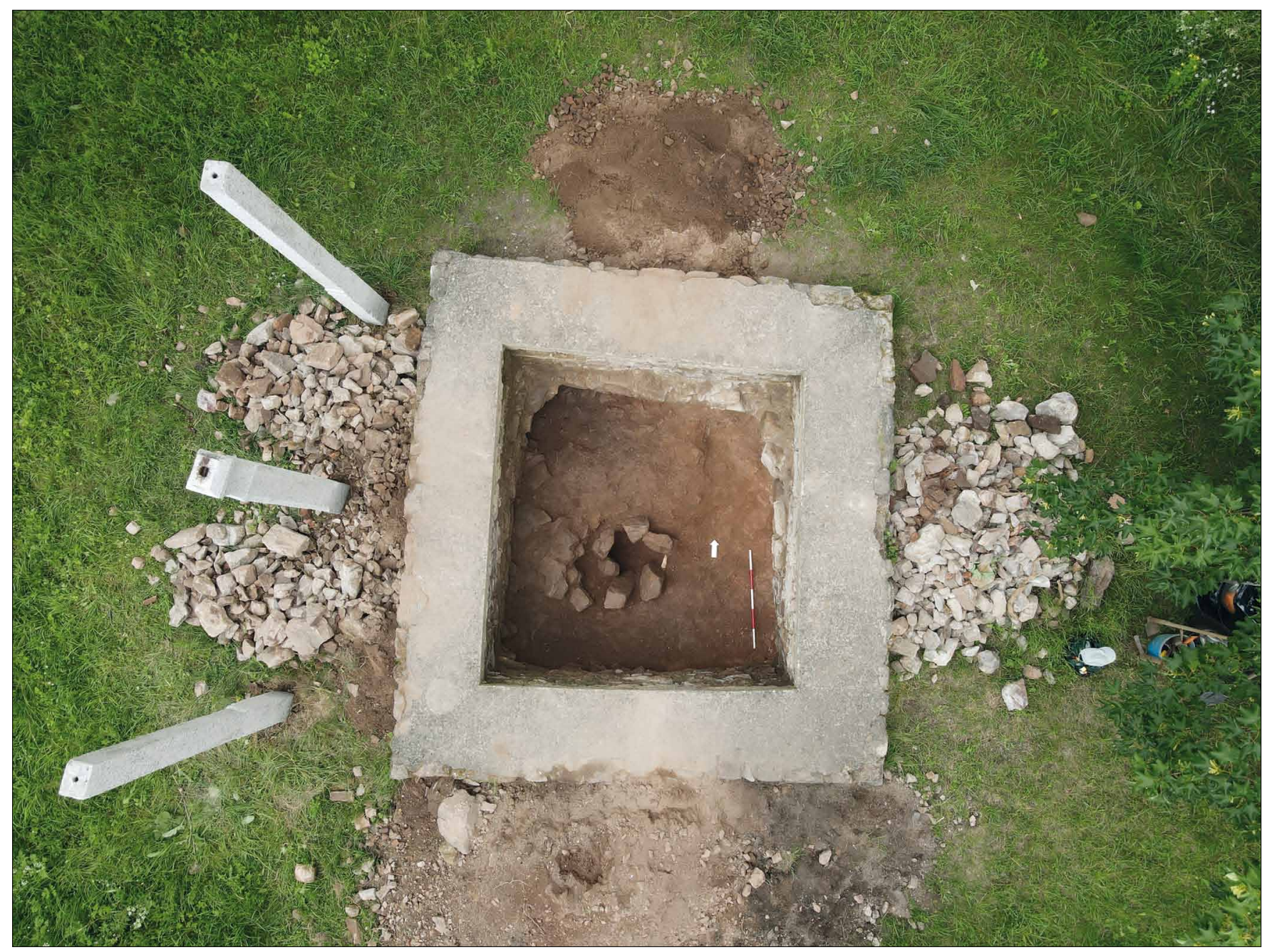

Obr. 6. Celkový pohled na prozkoumanou část šibenice poř́izený dronem. Foto: A. Navrátil.

V této vrstvě byly nalezeny převážně recentní nálezy v podobě střepů skleněných pivních láhví a nádob, kovových zátek a zbytky recentního ohniště. Po odstranění této vrstvy byla začištěna vrstva tmavě hnědé až černé hlíny.

Vrstva 2 (hloubka 5-20 cm). Vrstva tmavé hnědé až černé zeminy (hlíny) s ojedinělými recentními nálezy (střepy pivních lahví, zlomky recentní keramiky, kachliček a hřebíků) a kameny patrně z rozrušeného zdiva ohrazení šibenice.

Vrstva 3 (hloubka 20-40 cm). Vrstva tmavé zeminy s větším množstvím zlomků tmavé malty, kamenů, ojedinělými fragmenty lidských a zvírecích kostí, zlomků novověké keramiky a skla. Dobře rozeznatelná byla vrstva zlomků lastur a perletových polotovarů, zejména v podobě odpadních částí po výrobě knoflíků. Patrné byly zásahy související s betonáží koruny dochovaného zdiva $\mathrm{z}$ roku $1988 \mathrm{v}$ podobě reliktů dřevěného bednění a stopy recentního ohniště. Ve středu vrstvy byla identifikována jáma se světlejší zeminou související patrně s výstavbou původního dřevěného (?) křiže.

Vrstva 4 (hloubka 40-70 cm). Vrstva světlé zeminy (hlíny) tvořené světlou maltou. Do hloubky $50 \mathrm{~cm}$ zasahovaly nálezy lastur a perletářského odpadu, zlomky novověké keramiky a skla, ojedinělý byl nález lidských a zvírecích kostí. Od hloubky $60 \mathrm{~cm}$ byly četnější nálezy roztroušených lidských a zviŕecích kostí, zlomků polévané keramiky (datovatelné do 17. století), střepy tenkostěnných nádob, nepolévané keramiky (patrně z 16. století) a zlomky tmavě zabarveného skla. V hloubce $70 \mathrm{~cm}$ byla nalezena část skeletu v anatomické poloze (skelet 3 ). U skeletu byla nalezena stř́ibrná mince - jednostranný denár Zikmunda III. Vasy (1587-1632), bez datace, ražený v mincovně Włochowo (Polsko). Při prospekci vyvezené výplně byla nalezena další stříbrná mince - bílý peníz Rudolfa II. (1552-1612) z roku 1583, ražený v Kutné Hoře. Vrstva 5 (hloubka 70-95 cm). Vrstva bohatá na nálezy lidských a zvírecích kosterních pozůstatků. V hloubce kolem $80 \mathrm{~cm}$ bylo nalezeno několik anatomicky uspořádaných celků (části těl), označených jako skelet 1 , skelet 2 , skelet 4 a skelet 5 (Obr. 7), dále rozptýlené lidské a zvířecí kosti, včetně několika lebek, zlomky keramických nádob, zlomky tmavě zabarveného skla, ručně kovaných hřebíků, zlomek nože, srp (nalezen spolu s jednou $\mathrm{z}$ lebek) a pravděpodobně část železných pout. U skeletu 2 byla objevena stř́ibrná mince - oboustranný denár Zikmunda III. Vasy (1587-1632) z roku 1591, 


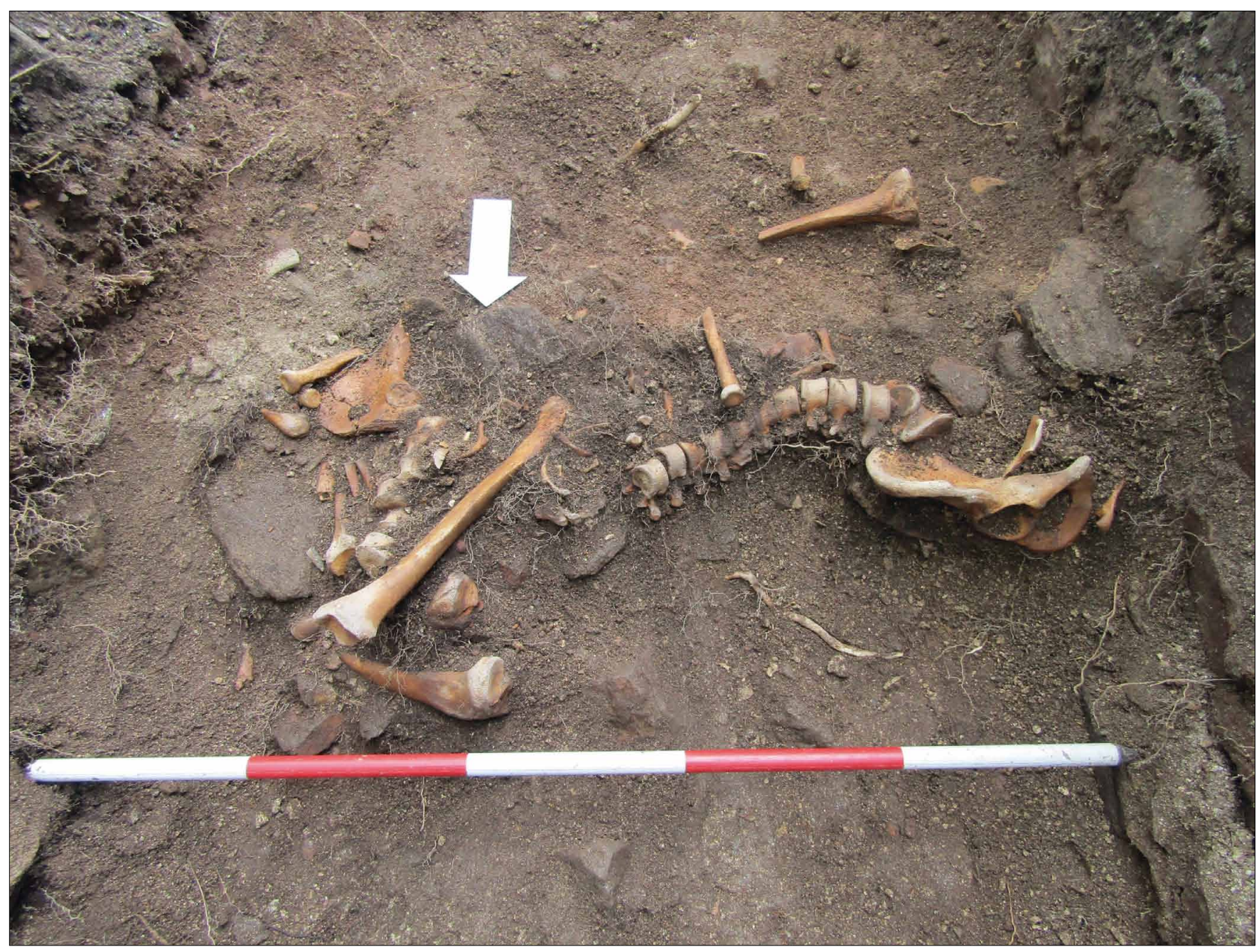

Obr. 7. Dochované ćásti skeletu 4. Foto: R. Pěnička.

ražený v Gdaňsku (Polsko). Při detektorovém průzkumu byla nalezena stř́ibrná mince - bílý peníz Vladislava II. Jagellonského (1471-1516), bez datace (patrně typ XIII) a zapínání oděvu (háčky). Na dně přecházela vrstva do červeně zabarvené zeminy.

Vrstva 6 (hloubka 95-115 cm). Vrstva převážně červeně/rezavě zabarvené zeminy osahovala balvany, mezi nimiž se nacházely roztroušené lidské a zviřrecí kosti. V západní části šibenice byla nalezena krusta tvořená směsí vylité malty a hlíny (podlaha?). V JV rohu se nacházela jáma se skrumáží lidských kostí, zasahující částečně pod zdivo. V hloubce $100 \mathrm{~cm}$ přibližně ve stře$\mathrm{du}$ šibenice byla nalezena část těla $\mathrm{v}$ anatomické poloze (skelet 6). V blízkosti skeletu byla objevena stř́brná mince - jednostranný fenik Maxmiliána I. (1493-1519) nebo Ferdinanda I. (1526-1564), bez datace, ražený v Korutanech. Při detektorovém průzkumu bylo nalezeno zapínání $\mathrm{z}$ drátěného háčku.

Vrstva 7 (hloubka 115-140/150 cm). Vrstva červeně zbarvené zeminy byla tvořená rozvětranou skálou, maltou a kamením, včetně ojedinělých nálezů lidských kostí. Na jižní straně ohrazení šibenice byla dosažena základová spára, přičemž zdivo šibenice bylo založeno prrímo na skále. Přibližně ve středu dna, bliže k jižnímu zdivu, byl nalezen shluk kamenů tvořících ohraničení jámy pro dřevěný kůl. Několik kamenů tvořilo utěsnění původního dřevěného kůlu. Mezi kameny se dochovala lidská kost. V jihozápadní části šibenice byl odkryt neporušený hrob (H1). Mezi jámou se skrumáží kostí a hrobovou jámou $\mathrm{H} 1$ byla nalezena mince ze slitiny stř́ibra a mědi - oboustranný denár Zikmunda III. Vasy (1587-1632), patrně z roku 1608, ražený v Poznani (Polsko). V hloubce 140 až $150 \mathrm{~cm}$ bylo dosaženo dno výplně šibenice tvořené rozvětranou skálou.

Hrob H1. V JZ části šibenice byl na dně odkryt hrob, který respektoval na severní straně ohraničení jámy pro dřevěný kůl, na jižní a západní straně hrob přiléhal ke kamennému zdivu šibenice (Obr. 8). Hrobová jáma se lehce rýsovala (rozměry: délka $145 \mathrm{~cm}$, šiŕka $56 \mathrm{~cm}$, hloubka v oblasti hlavy $115 \mathrm{~cm}$ a v oblasti pánve $150 \mathrm{~cm}$ ), orientace hrobu byla $\mathrm{Z}-\mathrm{V}$ (azimut $90^{\circ}$ ). Na dně hrobu byl uložený skelet nedospělého jedince (pravděpodobně chlapce ve věku kolem 13 let), položený na zádech, lebka se nacházela o něco výše než tělo a byla položena na kameni, horní končetiny byly podél těla a dolní končetiny byly natažené. Nad levým ramenem bylo nalezeno zapínání z drátěného očka, 


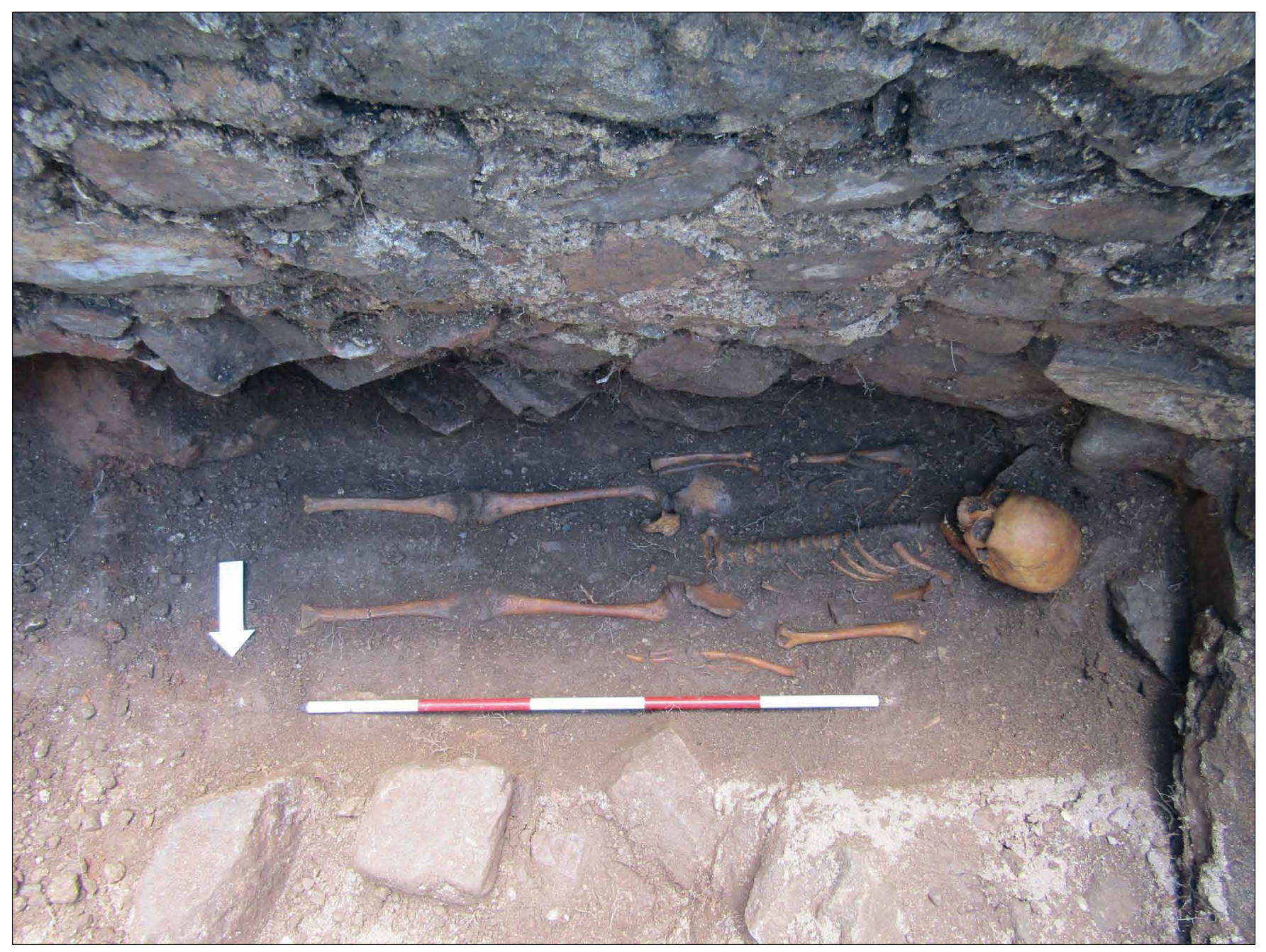

Obr. 8. Nálezová situace hrobu H1. Foto: R. Pěnička.

u pravé stehenní kosti byly nalezeny tř̌i kovové knoflíky. Ve vyvezené zemině pak bylo nalezeno zapínání z drátěného háčku. Při prohlídce okolního terénu na vrcholu Šibeniční hory byl identifikován průběh původního ohrazení areálu popraviště. $\mathrm{V}$ místě patrné terénní hrany byla provedena zjištovací sondáž (sondy S I až S IV) s cílem odhalit původní ohrazení areálu popraviště. Předpokládané ohrazení však nebylo sondáží detekováno z důvodu výrazných antropogenních změny terénu na vrcholu Šibeniční hory. Pouze v sondě III a IV byly nalezeny shluky kamenů, které mohou tvořit pozůstatky původního ohrazení areálu popraviště.

Archeologickým výzkumem se podařilo odkrýt vnitřní výplň zděné šibenice s pozůstatky popravených osob a dalším materiálem souvisejícím s aktivitami na popravišti. Výsledky výzkumu šibenice je nutné prozatím považovat za předběžné, přesto již lze vyvodit několik závěrů. Na základě hodnocení skladby kamenů tvořících obvodní zdivo šibenice pozorujeme dvě stavební fáze kamenné šibenice, které patrně souvisí s obnovou městských práv na konci 16. století. Nejstarší stavební fázi tvoří zbytky jámy pro dřevěný kůl utěsněný několika kameny. Nález lidské kosti mezi kameny, a také nález kostí uložených v jámě zasahující pod zdivo šibenice, dokládá výkon hrdelního práva $\mathrm{v}$ období před vybudováním kamenné i dřevěné šibenice, tedy do období na přelomu 15. století, př́íp. přelomu 15. a 16 . století.

Z výplně vnitřního prostoru šibenice byl získán bohatý antropologický i archeologický materiál svědčící o výkonu hrdelního práva od 15. do 17. století. Z mladšího období, tedy 18. století, nejsou nálezy rozeznatelné, což může naznačovat výrazný pokles významu bystřického hrdelního soudu. Z jednotlivých vrstev byla získána keramika, kterou lze datovat od přelomu 15. a 16. století až po současnost. Nálezy mincí (Obr. 9, Obr. 10) dovolují dataci kosterních pozůstatků především do období 15. až 17. století. Bohatý osteologický materiál je tvořen zejména rozptýlenými lidskými i zvířecími kostmi. Několik anatomicky uspořádaných částí koster dokládají běžné praktiky výkonu hrdelního práva, kdy tělo oběšence viselo na šibenici až do samovolného rozpadu a následně bylo v šibenici zahrabáno celé tělo nebo jen jeho části. Za zcela ojedinělý nález lze považovat hrob nedospělého chlapce (?) ve věku kolem 13 let. Také archeologický materiál poskytuje mnoho dokladů nejen o stavebním vý- 


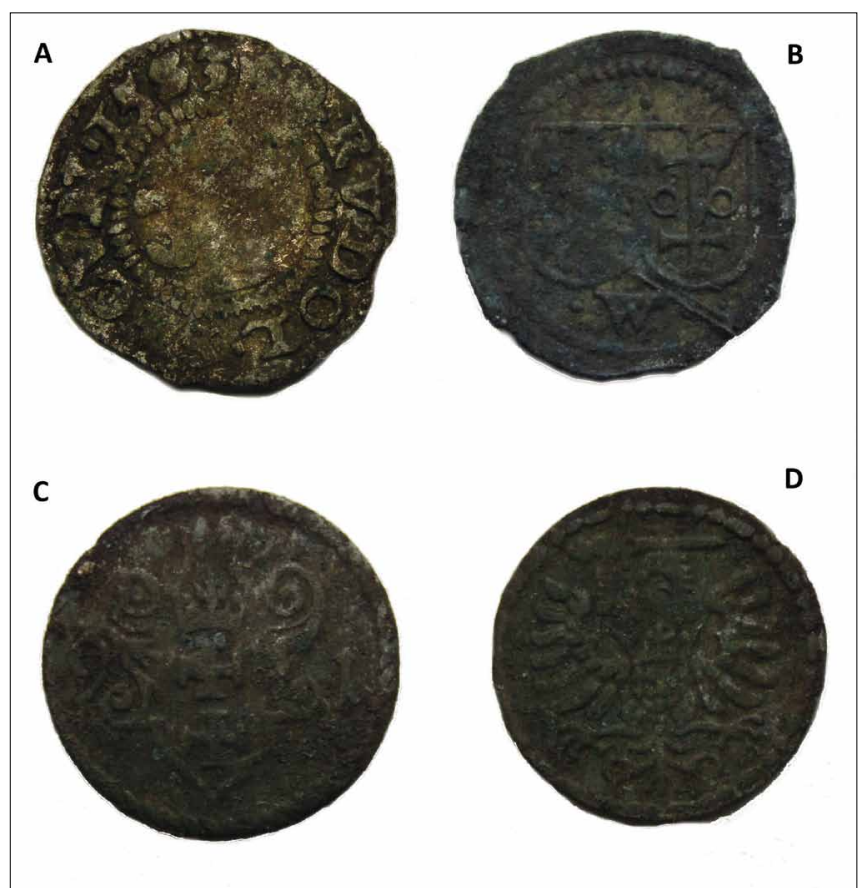

Obr. 9. Mince nalezené $\mathrm{v}$ šibenici I (bez měřítka). A - jednostranný bílý peníz Rudolfa II., 1583; B - jednostranný denár, Zikmund III. Vasa, bez datace, Włochowo (Polsko); C, D - oboustranný denár, Zikmund III. Vasa, 1519, Gdańsk (Polsko). Foto: R. Pěnička.

voji popraviště, ale umožňuje upřesnit datování nalezených kosterních pozůstatků.

Podle dochovaných archivních fotografií bylo okolí šibenice vymezeno kamennou zídkou. Sondáží se však tento předpoklad nepodařilo potvrdit, nebot celý sledovaný prostor byl výrazně pozměněn antropogenní činnosti při výstavbě lyžařského vleku. Detekování původního reliéfu v okolí šibenice, včetně kamenného ohrazení a detekce kosterních pozůstatků popravených, je proto složité a značně omezené.

\section{LITERATURA}

Balážová, Zuzana (2018): Popraviská z Brno-venkov. Jižní Morava, 54(57), s. 339-346.

Čuta, Martin - Mořkovský, Tomáš (2017): Antropologické zhodnocení kosterních pozůstatků ze slavkovské šibenice u Křenovic. Anthropologia Integra, 8(2), s. 15-24.

Evers, Thies (2008): Richtstätten in zeitgenössischen Bildquellen. Typologie und Topographie. In: Auler, Jost, Hrsg.: Richtstättenarchäologie. Dormagen: Archeotopos, s. 444-465.

Havlát, Josef - Kirchner, Karel - Lacina, Jan - Divíšek, Jan (2015): Cesta k tišnovské šibenici. Vlastivědný věstník moravský, 67(3), s. 278-285.

Jurkovičová, Lenka (2017): Archeozoologické spracovanie zvieracích pozostatkov zo šibenice při Slavkove. Anthropologia Integra, 8(2), s. 31-35.

Káčerková. Michaela - Boriová, Soňa (2019): Zvířecí kosti z ivančické šibenice. Jižní Morava, 55(58), s. 180-186.

Kirchner, Karel (2020): Bystřice nad Pernštejnem - šibenice na Šibenné hoře. Nepublikovaná výzkumná zpráva, $2 \mathrm{~s}$.

Křápková, Alica (2017): Šibenice na Hodonínsku v podkladoch prvého vojenského mapovania. Jižní Morava, 53(56), s. 137-151.
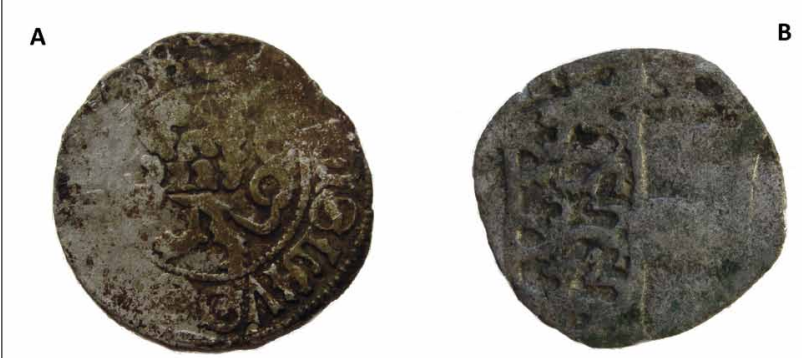

C

D
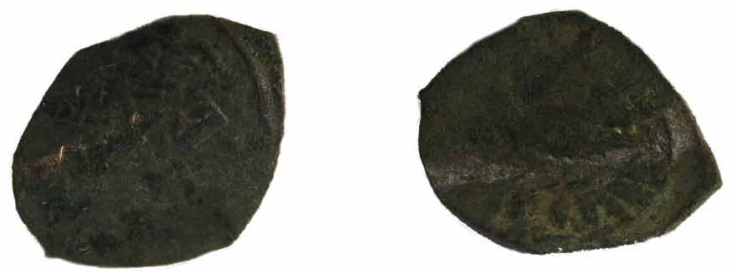

Obr. 10. Mince nalezené v šibenici II (bez měřítka). A - jednostranný bílý peníz, Vladislav II. Jagellonský, bez datace; B - jednostranný fenik, Maxmilián I./Ferdinand I., bez datace, Korutany; C, D - oboustranný denár, Zikmund III. Vasa, 1608, Poznań (Polsko). Foto: R. Pěnička.

Pěnička, Robin (2014): Kostrové nálezy a zacházení s těly zemřelých na šibenici v Tišnově. Vlastivědný věstník moravský, 66 (Supplementum), s. 161-163.

Pěnička, Robin (2017a): Kosti delikventů z popraviště „Na Stínadlech“ ve Strážnici. Jižní Morava, 53(56), s. 240-243.

Pěnička, Robin (2017b): Rekonstrukce a vizualizace podoby obličeje muže ze slavkovské šibenice. Anthropologia Integra, 8(2), s. 25-29.

Pěnička, Robin (2019): Lidské kosterní pozůstatky z ivančické šibenice. Jižní Morava, 55(58), s. 169-179.

Smrčková, Zdeňka (2020): Člověk a šibenice na západní Moravě. Brno. Diplomová práce. Masarykova univerzita, Př́rodovědecká fakulta.

Štarha, Ivan (1970): Královéhradecké městské právo na Moravě. Vlastivědný věstník moravský, 22(3), s. 306-312.

Štarha, Ivan (1998): Hrdelní soudy na Ždársku - I. část. Západní Morava, 2, s. 3-17.

Štarha, Ivan (2007): K rozšíření brněnského práva na Vysočině. Hrdelní soudnictví na Bystřicku. Forum Brunense: sborník prací Muzea města Brna, 1, s. 133-142.

Tenora, Jan (1907): Vlastivěda moravská II. Místopis. Bystřický (n. P.) okres. Brno: Musejní spolek v Brně, $272 \mathrm{~s}$.

Tenora, Jan (1909): Z pamětí města Bystřice nad Perštýnem. Brno: Benediktýnská knihtiskárna, $209 \mathrm{~s}$.

Unger, Josef (2014): Tišnovská šibenice. Vlastivědný věstník moravský, 66 (Supplementum), s. 152-160.

Unger, Josef (2017a): Archeologický výzkum slavkovské šibenice u Křenovic Anthropologia Integra, 8(2), s. 7-13.

Unger, Josef (2017b): Nové poznatky a nové problémy šibenice u Vranova nad Dyjí. Jižní Morava, 53(56), s. 236-239.

Unger, Josef (2019a): Jihomoravské šibenice - dokumentace, výzkum, památková péče a prezentace veřejnosti. Vlastivědný věstník moravský, 71(2), s. $120-126$.

Unger, Josef (2019b): Archeologický výzkum ivančické šibenice. Jižní Mora$v a, 55(58)$, s. 157-168.

Unger, Josef - Divíšek, Jan - Kirchner, Karel - Kuda, František - Lacina, Jan 
- Balážová, Zuzana (2016): Lomnická šibenice. Vlastivědný věstník moravský, 68(1), s. 23-29.

Unger, Josef - Boriová, Soňa - Čuta, Martin - Divíšek, Jan - Halas, Petr Křápková, Alica - Lacina, Jan - Mořkovský, Tomáš - Pěnička, Robin - Velek, Jan - Wojtucki, Daniel (2020): Jihomoravské šibenice v časném novověku (16. až 18. stol.). Brno: Masarykova univerzita. $147 \mathrm{~s}$.

Virdzeková, Alica (2016a): Stredoveké a rano-novoveké popraviská vo svetle archeologických prameňov. Brno. Diplomová práce. Masarykova univerzita. Filozofická fakulta.

Virdzeková, Alica (2016b): Šatovská šibenica. Jižní Morava, 52(55), s. 399405.

Wojtucki, Daniel (2005): Popraviště v Čechách a na Moravě od 16. do 19. století. Sborník Společnosti pro výzkum kamenných křižů, s. 27-41.

\section{ELEKTRONICKÉ ZDROJE}

I. vojenské (josefské) mapování. [online]. Dostupné z: http://oldmaps.geolab. cz/map_viewer.pl?lang=cs\&map_root $=1$ vm\&map_region $=$ mo\&map_ list $=\mathrm{m} 035$
II. vojenské (Františkovo) mapování. [online]. Dostupné z: http://oldmaps. geolab.cz/map_viewer.pl?lang=cs\&map_root $=2 \mathrm{vm} \&$ map_region $=$ mo\&map_list=W_7_I

III. vojenské mapování. [online]. Dostupné z: http:/oldmaps.geolab.cz/map region.pl?lang=cs\&map_root=3vm\&map_region $=25$

\section{AUTOR}

Pěnička, Robin, RNDr. Ph.D. $\left({ }^{\star} 1984\right)$, antropolog. Po studiu antropologie naPř́rodovědecké fakultě Masarykovy univerzity působí na Ústavu antropologie PřF MU jako lektor. Ve výzkumné činnosti se věnuje kosterní antropologii, antropologii smrti a antropologii globalizace. $\mathrm{V}$ interdisciplinárním týmu věnujícího se fenoménu moravských popravišt zajištuje antropologické hodnocení nálezů. Kontakt: Ústav antropologie, Př́rodovědecká fakulta Masarykovy univerzity, Kotlářská 267/2, 61137 Brno; email: robin.penicka@ gmail.com. 